\title{
EXPRESSION LEVELS OF SEX HORMONE RECEPTORS IN BRAINS OF JAPANESE MEDAKA, ORYZIAS LATIPES (ACTINOPTERYGII: BELONIFORMES: ADRIANICHTHYIDAE)
}

\author{
Arin NGAMNIYOM ${ }^{1 *}$ and Yuichi SASAYAMA ${ }^{2}$ \\ ${ }^{1}$ Srinakharinwirot University, Institute of Eco-tourism, 10110, Bangkok, Thailand \\ ${ }^{2}$ Kanazawa University, Division of Biodiversity, Institute of Nature and Environmental Technology, \\ 920-1192, Kanazawa, Ishikawa, Japan
}

Ngamniyom A., Sasayama Y. 2011. Expression levels of sex hormone receptors in brains of Japanese medaka, Oryzias latipes (Actinopterygii: Beloniformes: Adrianichthyidae). Acta Ichthyol. Piscat. 41 (1): 29-35.

Background. In teleost fishes, the brain is the target organ for sex steroid hormones. The actions of sex steroid hormones are mediated by their receptors and play an important role in the regulation of endocrine function in the brain. Japanese medaka, Oryzias latipes, is a species widely used in many fields of experimental biology, including neurobiology. In this study, we examined the mRNA expression levels of androgen and estrogen receptors in medaka brains.

Materials and methods. The brains of adult fish were separated into three parts (forebrain, midbrain and hindbrain). The expression levels of androgen receptor $(A R)$ and estrogen receptor $(E R) \beta$ from each part of the brain were determined using a semi-quantitative RT-PCR analysis.

Results. $A R$ and $E R \beta$ levels in males were higher in the forebrain and midbrain than in the hindbrain. In females, $A R$ and $E R \beta$ levels were higher in the forebrain than in the midbrain and hindbrain. $A R$ levels in the forebrain and midbrain of males were higher than those of females. Conversely, there was no difference in $E R \beta$ level between males and females.

Conclusion. These data on hormone receptors provide the foundation for understanding the molecular basis of $A R$ and $E R \beta$ mRNA expression levels in medaka brains. In addition, our results suggest that, in Japanese medaka, $A R$, but not $E R \beta$, expression may exhibit sexual dimorphisms between males and females in the forebrains and midbrains.

Keywords: androgen receptor, estrogen receptor $\beta$, brain, Japanese medaka, Oryzias latipes

\section{INTRODUCTION}

In many teleosts, sex steroid hormones play a crucial role in the physiological processes of many tissues, such as liver, gonad, kidney and bone (Jakobsson et al. 1996, Socorro et al. 2000, Amer et al. 2001, Riley et al. 2002, Ngamniyom et al. 2009).

It is known that, the brain is also the target tissue for the actions of sex steroid hormones, suggesting that these hormones are important in modulating differences in brain functions (Bernadi and Genazzani 1999).

Weltzien et al. (2004) and Munakata and Kobayashi (2010) have reported that sex steroid hormones, androgen and estrogen, play an important role in the sex behaviours and the action of gonadotropin secretion in the central nervous system of teleost fish. Androgen signals their target cells via androgen receptors $(A R s)$ as the sex steroid controlling male sexual differentiation (Jenster et al. 1995, Oliveira et al. 2002). Paralleling androgen function, estrogen functions in females via estrogen receptors (ERs) (Nilsson et al. 2001). However, three isoforms in $E R s$, designated as $E R \alpha, E R \beta$, and $E R \gamma$, have also been reported in vertebrates (Chang et al. 1999, Sabo-Attwood et al. 2004). Especially, in teleosts, $E R \beta$ is abundantly expressed in several organs, such as the liver, gonads and brain (Menuet et al. 2002, Hawkins and Thomas 2004). This fact suggests that, among $E R s, E R \beta$ is the main $E R$ in fish.

The Japanese medaka (also know as the Japanese rise fish), Oryzias latipes, is a model organism widely utilized for experiments in various fields such as neurobiology, developmental biology and endocrinology (Ishikawa 1997, Zhang et al. 2008, Mezhoud et al. 2009). Attributes of the medaka that make it an advantageous as an experimental animal are its small size, it is easy to keep, and its sexual dimorphism is external (Parenti 2008). Therefore, we believed that elucidation of $A R$ and $E R \beta$ expression in medaka brains might contribute to increasing our knowl-

\footnotetext{
* Correspondence: Dr. Arin Ngamniyom, Srinakharinwirot University, Institute of Eco-tourism and Biodiversity, 10110, Bangkok, Thailand, phone: +662-204-2165, fax:+662-258-4007, e-mail: ngamniyom.a@gmail.com or arin8116@staff.kanazawa-u.ac.jp.
} 
edge of the regulation of sex steroid hormones in teleost.

In this study, we provided the molecular-biological background of the forebrain, midbrain and hindbrain of male and female adult Japanese medaka by examining mRNA expression levels of the androgen receptor $(A R)$ and estrogen receptor $(E R) \beta$.

\section{METERIAL AND METHODS}

Adult Japanese medaka were purchased from a commercial source in Kanazawa city, Ishikawa, Japan. Their standard length was 24-26 mm. Males and females were kept separately in aquaria with a controlled $14: 10 \mathrm{~h}$ light/dark photoperiod cycle at $26 \pm 1{ }^{\circ} \mathrm{C}$ for 2 weeks, and fed ad libitum with TetraMin (Tokyo, Japan). Their sexes were judged from the morphology of the secondary sex characters of the dorsal and anal fins, according to the criteria of Okada and Yamashita (1944). This experiment was conducted from August 2009 through the end of February 2010.

Adult males and females were anesthetized with $200 \mathrm{mg} \cdot \mathrm{L}^{-1}$ of an ethyl-3-aminobenzoate methanesulphonate (MS-222) solution (Sigma, St. Louis, MO) and placed in a Petri dish. Brain fish was precisely separated to three parts, according to the criteria of Ishikawa et al. (1999). The part of tepencephalon to the part of diencephalon was distinguished from midbrain as the forebrain. The part of nervus opticus until the posterior end of tectum opticum was indentified such the midbrain. The hindbrain was composed of the metencephalon and myelencephalon. The forebrains, midbrains, and hindbrains were dissected out from 10 male and 10 female fish (Fig. 1). Each part of brain was contained into each tube, and a sample of 10 tubes was collected.
Total RNA from each sample of medaka brains was extracted by using RNeasy Fibrous Tissue Mini Kit (Qiagen, Tokyo, Japan) according to the manufacturer's protocol and treated with DNasel (Takara, Tokyo, Japan) for $30 \mathrm{~min}$ at $37^{\circ} \mathrm{C}$. Total RNA (100 $\mathrm{ng}$ ) was reverse-transcribed with AMV reverse transcriptase XL (Takara, Tokyo, Japan) according to the manufacturer's instructions. The extract solution $(0.5 \mu \mathrm{L})$ was used as a PCR template. Primers for amplification of $A R$ (5' CAGGAG--GAGTTC-CTGTGCAT-3' and 5'-GGTGGTGGTAAG-GTGAAG-GA-3') were designed from a sequence (accession number AB076399). ER $\beta$ primers were 5'-CTGTTAGATGC-CTCGGACCTT-3' and 5'-GATTG-GCTGGTTTCGTG-3' (Inui et al., 2003). As a loading control and reference, $\beta$-actin mRNA was amplified for each RT reaction; primers used were 5'-AGGGAGAA-GATGACC-3' and 5'-CGCAGGACGCCATACCAA-3' (Scholz et al. 2004). PCR conditions for the amplification of cDNA were $95^{\circ} \mathrm{C}$ for $30 \mathrm{~s}$ for denaturation; $62^{\circ} \mathrm{C}(A R), 64^{\circ} \mathrm{C}(E R \beta)$, or $58^{\circ} \mathrm{C}$ ( $\beta$-actin) for $45 \mathrm{~s}$ for annealing; and $72^{\circ} \mathrm{C}$ for $1 \mathrm{~min}$ for extension. The RT-PCRs of linear phases were determined on 20-32 cycles for $\beta$-actin and 32-44 cycles for hormone receptors to allow semi-quantitative comparisons of cDNAs which were developed for the optimum reactions (Figs. 2-4). Therefore, cycle numbers for $A R$ and $E R \beta$ were 36 cycles, and for $\beta$-actin were 26 cycles. PCR products were electrophoresed on $2 \%$ agarose gel, stained with ethidium bromide, and visualized on a UVtransilluminator (Figs. 2-4). Amplification levels were quantified by using Scion Image software for Windows (Scion, Maryland, USA). Amplification levels of $A R$ and $E R \beta$ for each brain type were divided by the corresponding amplification level of $\beta$-actin to obtain relative expression levels (Fig 5).

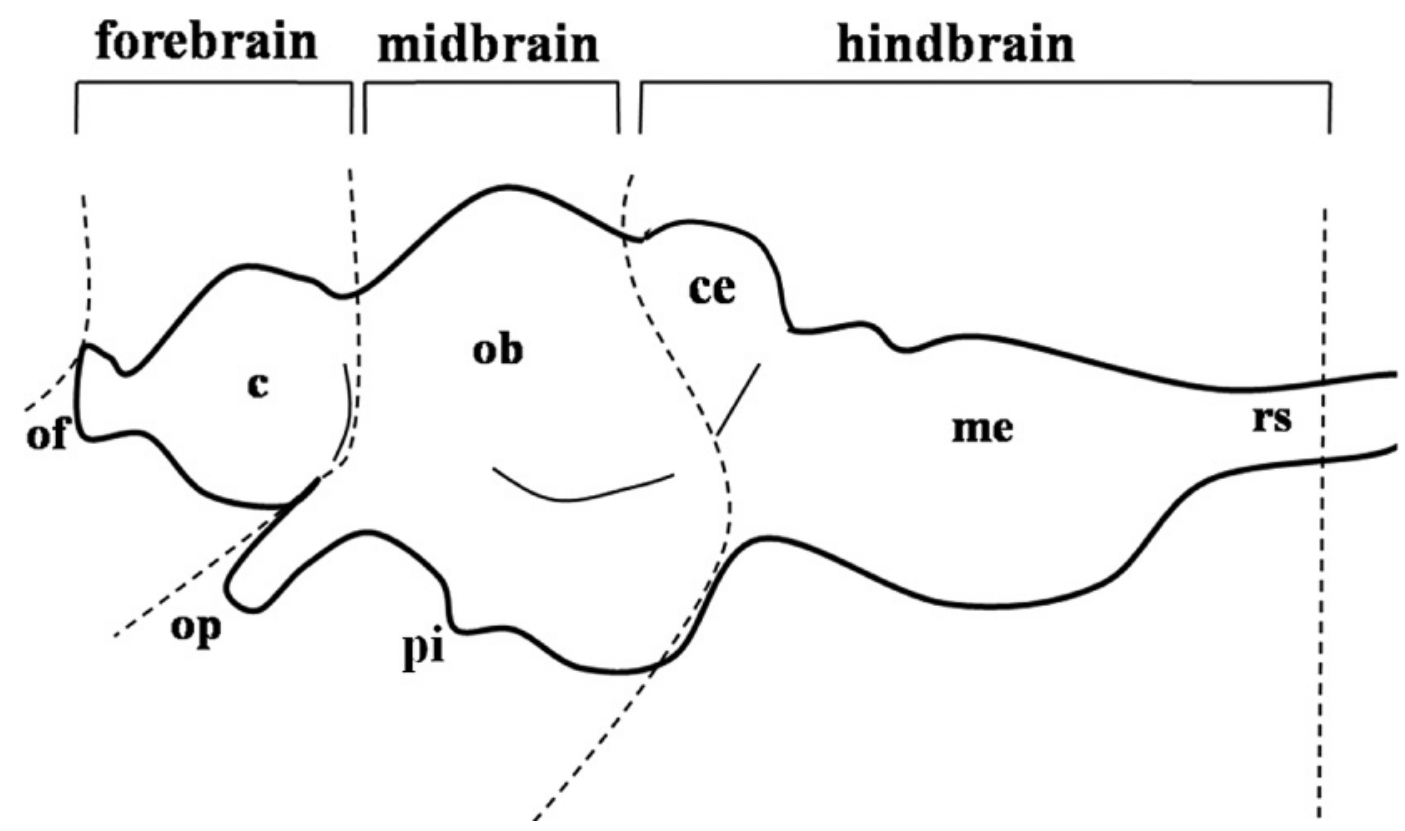

Fig. 1. Lateral view of diagrammatic illustration of brain of Japanese medaka, Oryzias latipes; The whole brain was separated to the forebrain, midbrain and hindbrain; Abbreviations: of, olfactory bulb; c, cerebrum; op, optic nerve; ob, optic lobe; pi, pituitary; ce, cerebellum; me, medulla; rs, rostral spinal cord 
One-way ANOVA with Tukey's multiple comparison test and the unpaired Student's $t$-test were used to examine differences statistically. Data were analyzed by using the statistical package for the social sciences (SPSS) for Windows, version 14 (SPSS, Chicago, USA).
This experiment design was approved by the ethics committee of the Kanazawa University, Institute of Nature and Environmental Technology, Japan, in accordance with the recommendations of The Littlewood Declaration (Lane-Petter 1976).
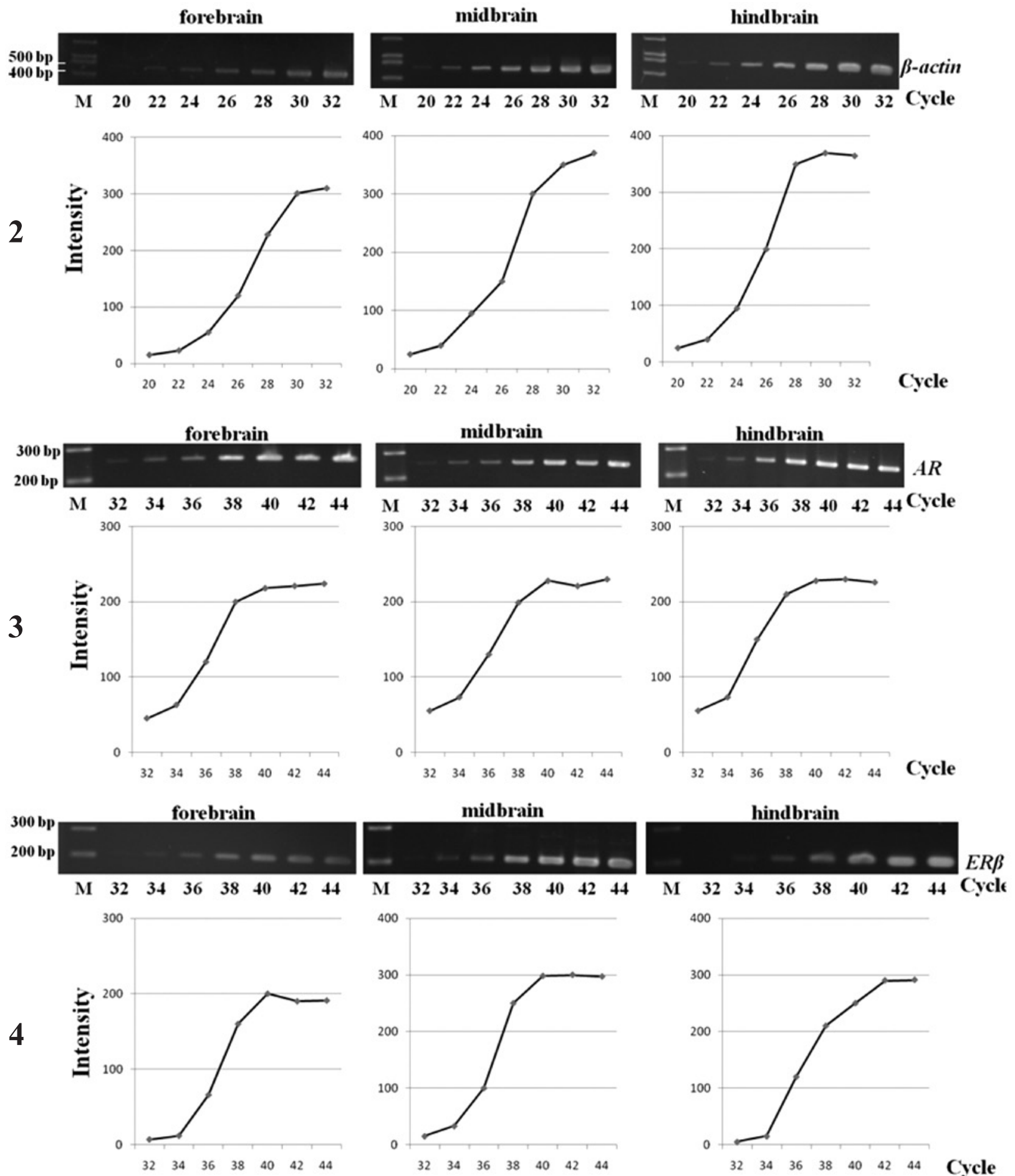

$\begin{array}{llllllll}32 & 34 & 36 & 38 & 40 & 42 & 44 & \text { Cycle }\end{array}$

Figs. 2-4. Gel electrophoresis of RT-PCR analysis and graphs of linear phase in various cycles of (Fig. 2) $\beta$-actin,

(Fig. 3) $A R$ and (Fig. 4) $E R \beta$ mRNA expression in Japanese medaka, Oryzias latipes; The optimal numbers of cycle condition were identified at a slope of linear graph; Cycle numbers for $\beta$-actin were 26 cycles, and for AR and $E R \beta$ were 36 cycles; M, molecular marker 
Male
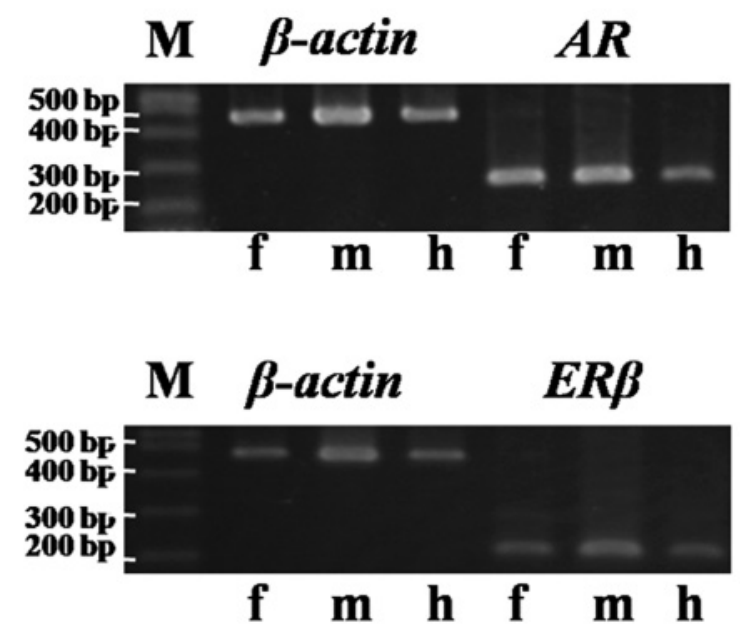

Female
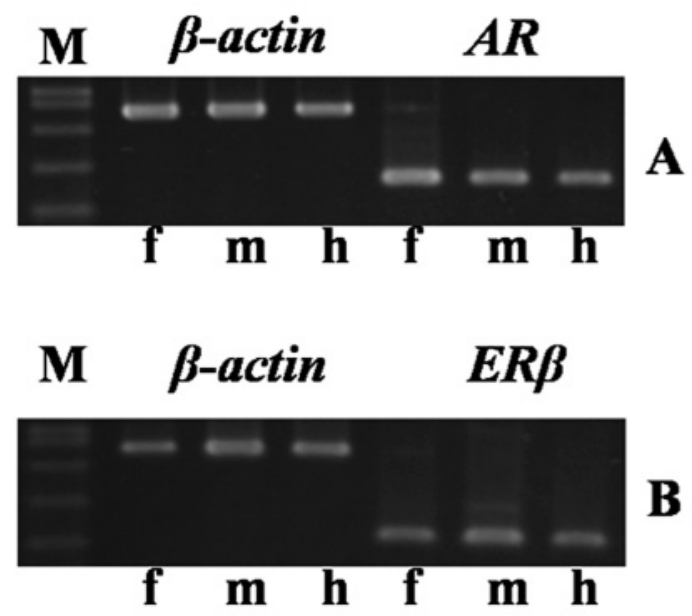

Fig. 5. Gel electrophoresis of semi-quantitative RT-PCR analysis of $\beta$-actin, $A R$ and $E R \beta$ mRNA expression in male and female medaka. M, molecular marker; f, forebrain; m, midbrain; h, hindbrain

\section{RESULTS}

Levels of $A R$ mRNA expression in the medaka brain. In males, the levels of $A R$ mRNA expression were significantly higher in the forebrain and midbrain than in the hindbrain (Fig. 6). In females, levels of $A R$ mRNA expression were significantly higher in the forebrain than in the midbrain and hindbrain (Fig. 7). The expression levels of $A R$ mRNA in the forebrain and midbrain were significantly higher in males than in females (Fig. 8). In contrast, no significant difference in $A R$ mRNA expression level was found in the hindbrain between males and females (Fig. 8).

Levels of ERß mRNA expression in the medaka brain. In males, the levels of $E R \beta$ mRNA expression were significantly higher in the forebrain and midbrain than in the hindbrain (Fig. 9). In females, levels of $E R \beta$ mRNA expression were also significantly higher in the forebrain than in the midbrain and hindbrain (Fig. 10). No significant difference in $E R \beta$ mRNA expression level was found between males and females for any of the brain regions (Fig. 11).

\section{DISCUSSION}

In both sexes of medaka, $A R$ mRNA expression levels were higher in the forebrain and midbrain than in the hindbrain. This finding is consistent with the report of Forlano et al. (2010) that $A R$ mRNA expressions was higher in the forebrain and midbrain region than in the hindbrain region of midshipman fish, Porichthys notatus. It is known that, in teleost fish, $A R$ expression is high in the anterior and mid-regions of the brain, including the pituitary region, suggesting that androgen may act on those target regions to control the sexual behaviour of males (Burmeister et al. 2007). Thus, the strong expression of $A R$ mRNA in the forebrain and midbrain may support the role of androgen as a regulator of physiological behaviour of male fish. However, it is too soon to hypothesise that the brain contains the specific target tissues of androgen since $A R$ expression in situ has not been elucidated in the medaka brain.

It is well known that androgen exerts its action in the brain directly via androgen receptors or via estrogen receptors after aromatisation to estrogen (Pasmanik and Callard 1988). In female fish, estrogen synthesis from androgen may be required to activate estrogen receptors. When the expression levels of sex steroid hormones were compared between males and females, $A R$ mRNA in the forebrain and midbrain was found to be more abundant in males than females. This result suggests that $A R$ mRNA expression level in the forebrain and midbrain may be a sexual dimorphism between male and female fish.

Similarly, the $E R \beta$ mRNA levels in males and females were higher in the forebrain and the midbrain than in the hindbrain. This result is consistent with the reports of Anglade et al. (1994) and Muriach et al. (2008) that ER expression was observed in the forebrain and midbrain areas of rainbow trout, Oncorhynchus mykiss, and European sea bass, Dicentrarchus labrax. Our results suggests that, in males, the forebrain and midbrain are also targets for estrogen, even though these parts of brain have thus far not been regarded as being deeply related to brain functions of male fish. In females, the expression levels of $E R \beta$ were higher in the forebrain and midbrain than in the hindbrain. This confirms that estrogen functions on these brain regions for the physiological processes of feminising in female teleosts.

This finding is consistent with the reports of Anglade et al. (1994) and Trudeau et al. (2005) that the ER $\beta$ levels were not different in the brains of male and female rainbow trout, Oncorhynchus mykiss, or goldfish, Carassius auratus. Therefore, ER $\beta$ mRNA expression level may not exhibit any sexual difference in the brain regions between 

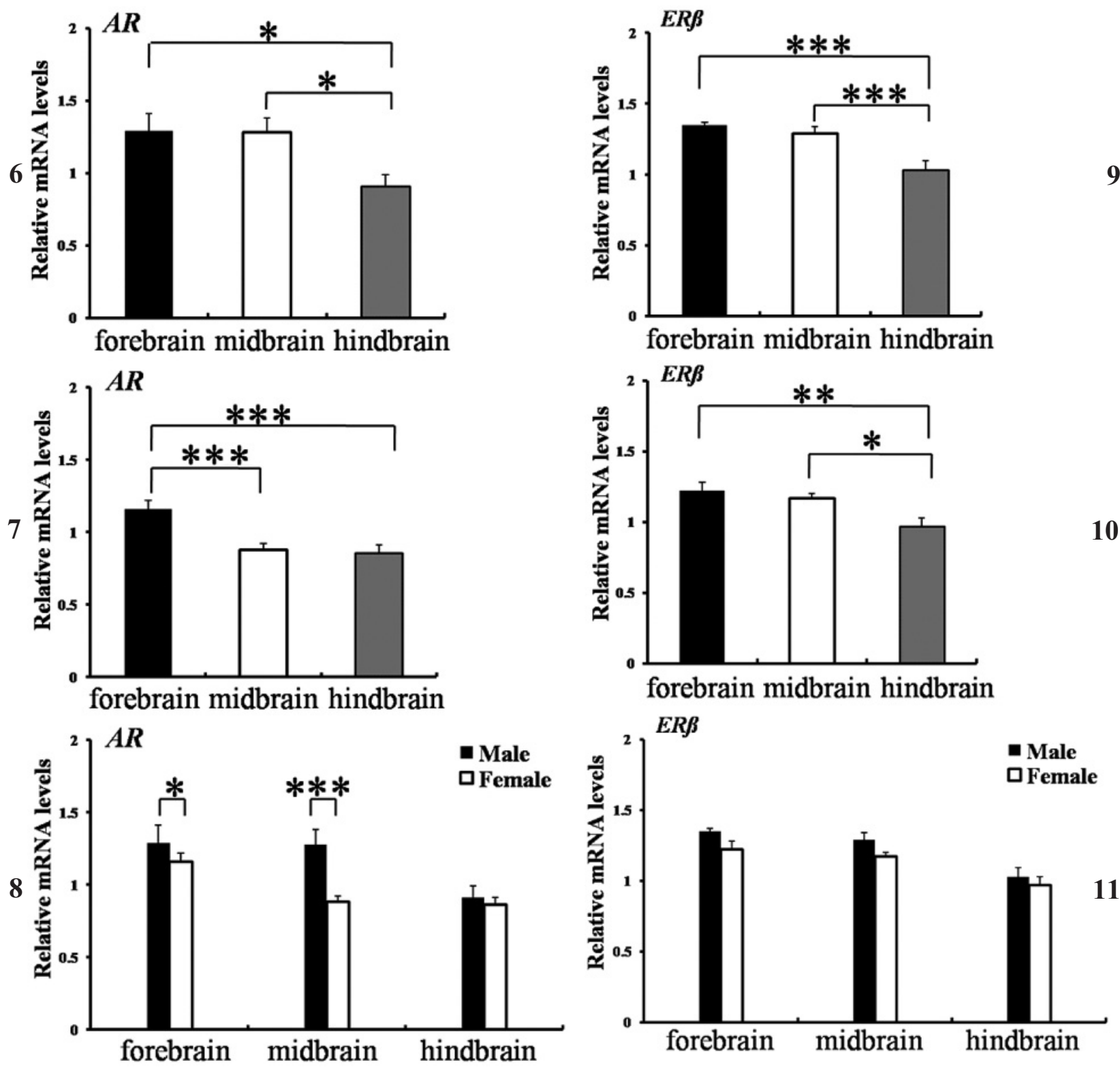

Figs. 6-11. Expression levels of $A R$ mRNA (Figs. 6-7) and $E R \beta$ mRNA (Figs. 9-11) in the forebrain, midbrain and hindbrain of Japanese medaka, Oryzias latipes; Fig. 6. $A R$ mRNA in male; Fig. 7. $A R$ mRNA in female; Fig 8. Comparison between $A R$ mRNA in male and female; Fig. 9. $E R \beta$ mRNA in male; Fig. 10. $E R \beta$ mRNA in female; Fig. 11. Comparison between $E R \beta$ mRNA in male and female; The expression levels in each part of brains are values relative to the expression level of $\beta$-actin mRNA (mean $\pm \mathrm{SE}$ ); One-way ANOVA followed by Tukey's multiple comparison test in Figs. 6, 7, 9 and 11 and by the unpaired Student's $t$-test in Figs. 8 and 11; $* P<0.05$, $* * P<0.01, * * * P<0.005$

male and female fish. Furthermore, it may be worthwhile to note that estrogenic control in the forebrain and midbrain of males is relatively similar to that of females because androgenic control of the forebrains and midbrains is abundant.

In many teleost fish, it is known that levels of sex hormone receptors between males and females are different in the gonads, liver, brains and blood serum depending on the season (Owen 1936, Iguchi et al. 1991, Du et al. 2004, Desjardins et al. 2006). In the breeding season, the levels of androgens were high in male oyster toadfish, Opsanus tau, and showed obvious sexual dimorphism (Fine et al. 2004). Schreck and Hopwood (1974) reported that estrogen lev- els in the female adult goldfish, Carassius auratus, were highest during the spawning season, indicating sexual dimorphism between males and females. In this study, the experiment was conducted from late August through February. This period was the non-breeding season of Japanese medaka (Shima and Mitani 2004). However, androgen levels were not different between males and females in the hindbrain, and no sexual dimorphism of estrogen level was found in the forebrain, midbrain or hindbrain. These results suggest that androgenic and estrogenic hormones are not necessary for acting and functioning on those target tissues. 
This study provides preliminary data of AR and $E R \beta$ expression in the brain of the Japanese medaka. To our knowledge, this is the first study on the genus Oryzias to examine the AR and $E R \beta$ mRNA expression levels across three regions of the brain.

\section{REFERENCES}

Amer M.A., Miura T., Miura C., Yamauchi K. 2001. Involvement of sex steroid hormones in the early stages of spermatogenesis in Japanese huchen (Hucho perryi). Biology of Reproduction 65 (4): 1057-1066. DOI: 10.1095/biolreprod65.4.1057.

Anglade I., Pakdel F., Baihache T., Petit F., Salbert G., Jego P., Valotaire Y., Kah O. 1994. Distribution of estrogen receptor-immunoreactive cells in the brain of the rainbow trout (Oncorhynchus mykiss). Journal of Neuroendocrinology 6 (5): 573-583. DOI: 10.1111/j.1365-2826.1994.tb00621.x.

Bernardi F., Genazzani A.R. 1999. The brain: target and source for sex steroid hormones. Women's health and menopause; Medical Science Symposia Series 13 (6): 137-143. DOI: 10.1007/978-0-585-37973-9_20.

Burmeister S.S., Kailasanath V., Fernald R.D. 2007. Social dominance regulates androgen and estrogen receptor gene expression. Hormones and Behavior 51 (1): 164-170. DOI: 10.1016/j.yhbeh.2006.09.008.

Chang X., Kobayashi T., Todo T., Ikeuchi T., Yoshiura M., Kajiura-Kobayashi H., Morrey C., Nagahama Y. 1999. Molecular cloning of estrogen receptors $\alpha$ and $\beta$ in the ovary of a teleost fish, the tilapia (Oreochromis niloticus). Zoological Science 16 (4): 653-658. DOI: 10.2108/zsj.16.653.

Desjardins J.K., Hazelden M.R., van der Kraak G.J., Balshine S. 2006. Male and female cooperatively breeding fish provide support for the "Challenge Hypothesis". Behavioral Ecology 17 (2): 149-154. DOI: 10.1093/beheco/arj018.

Du J.-L., Lee Y.-H., Yueh W.-S., Chang C.-F. 2004. Seasonal profiles of brain and pituitary gonadotropin-releasing hormone and plasma luteinizing hormone in relation to sex change of protandrous black porgy, Acanthopagrus schlegeli. Biology of Reproduction 72 (4): 922-931. DOI: 10.1095/biolreprod.104.033159.

Fine M.L., Johnson M.S., Matt D.W. 2004. Seasonal variation in androgen levels in the oyster toadfish. Copeia 2004 (2): 235-244. DOI: 10.1643/CP-03-073R1.

Forlano P.M., Marchaterre M., Deitcher D.L., Bass A.H. 2010. Distribution of androgen receptor mRNA expression in vocal, auditory, and neuroendocrine circuits in a teleost fish. Journal of Comparative Neurology 15 (4): 493-512. DOI: $10.1002 /$ cne.22233.

Hawkins M.B., Thomas P. 2004. The unusual binding properties of the third distinct teleost estrogen receptor subtype ERßa are accompanied by highly conserved amino acid changes in the ligand binding domain. Endocrinology 145 (6): 2968-2977. DOI: 10.1210/en.2003-0806.

Iguchi K., Ito F., Ikuta K., Yamaguchi M. 1991. [Sexual dimorphism in the anal fin of ayu, Plecoglossus altivelis.] Nippon Suisan Gakkaishi 57 (8): 1501-1505. [In Japanese.]

Inui M., Adachi T., Takenaka S., Inui H., Nakazawa M., Ueda M., Watanabe H., Mori C., Iguchi T., Miyatake K. 2003. Effect of UV screens and preservatives on vitel- logenin and choriogenin production in male medaka (Oryzias latipes). Toxicology 194 (1-2): 43-50. DOI: 10.1016/S0300-483X(03)00340-8.

Ishikawa Y. 1997. Embryonic development of the medaka brain. Fish Biology Journal Medaka 9: 17-31. http://hdl.handle.net/2237/13818.

Ishikawa Y., Yoshimoto M., Ito H. 1999. A brain atlas of a wild-type inbred strain of the medaka, Oryzias latipes. Fish Biology Journal Medaka 10: 1-26. http://ci.nii.ac.jp/naid/110007349045/en.

Jakobsson S., Mayer I., Schulz R.W., Blankenstein M.A., Borg B. 1996. Specific binding of 11-ketotestosterne in an androgen target organ, the kidney of the male three-spined strickback, Gasterosteus aculeatus. Fish Physiology and Biochemistry 15 (6): 459-467. DOI: 10.1007/BF01874920.

Jenster G., van der Korput H.A.G.M., Trapman J., Brinkmann A.O. 1995. Identification of two transcription activation units in the N-terminal domain of the human androgen receptor. Journal of Biological Chemistry 31: 7341-7346. DOI: 10.1074/jbc.270.13.7341.

Lane-Petter W. 1976. The ethics of animal experimentation. Journal of Medical Ethics 2 (3): 118-126.

Menuet A., Pellegrini E., Anglade I., Blaise O., Laudet V., Kah O., Pakdel F. 2002. Molecular characterization of three estrogen receptor forms in zebrafish: Binding characteristics, transactivation properties, and tissue distributions. Biology of Reproduction 66 (6): 1881-1892. DOI: 10.1095/biolreprod66.6.1881.

Mezhoud K., Praseuth D., Marie A., Puiseux-Dao S., Edery M. 2009. Medaka proteome study: Use of cross-species matching and expressed sequence tag data for protein identification. Journal of Proteomics and Bioinformatics 2: 67-77. DOI: $10.4172 / j p b .1000063$.

Munakata A., Kobayashi M. 2010. Endocrine control of sexual behavior in teleost fish. General and Comparative Endocrinology 165 (3): 456-468. DOI: 10.1016/j.ygcen.2009.04.011.

Muriach B., Carrillo M., Zanuy S., Cerda-Reverter J.M. 2008. Distribution of estrogen receptor 2 mRNAs (Esr2a and Esr2b) in the brain and pituitary of the sea bass (Dicentrachus labrax). Brain Research 1210: 126-141. DOI: 10.1016/j.brainres.2008.02.053.

Ngamniyom A., Magtoon W., Nagahama Y., Sasayama Y. 2009. Expression levels of hormone receptors and bone morphogenic protein in fins of medaka. Zoological Science 26 (1): 74-79. DOI: 10.2108/zsj.26.74.

Nilsson S., Mäkelä S., Treuter E., Tujague M., Thomsen J., Andersson G., Enmark E., Pettersson K., Warner M., Gustafsson J.A. 2001. Mechanisms of estrogen action. Physiological Reviews 81 (4): 1535-1565. http://physrev.physiology.org/content/81/4/1535.full.pdf.

Okada YK., Yamashita H. 1944. [Experimental investigation of the manifestation of secondary sexual characters in fish, using the medaka (Oryzias latipes) as material.] Journal of Faculty of Science University of Tokyo 6: 383-437. [In Japanese.]

Oliveira R.F., Hirschenhauser K., Carneiro L.A., Canario A.V.M. 2002. Social modulation of androgen levels in male teleost fish. Comparative Biochemistry and Physiolgy B 132 (1): 203-215. DOI: 10.1016/S1096-4959(01)00523-1. 
Owen S.E. 1936. The reaction of fish to sex hormones. Endocrinology 20 (2): 214-218. DOI: 10.1210/endo-20-2-214.

Parenti L.R. 2008. A phylogenetic analysis and taxonomic revision of ricefishes, Oryzias and relatives (Beloniformes, Adrianichthyidae). Zoological Journal of the Linnean Society 154 (3): 494-610. DOI: 10.1111/j.1096-3642.2008.00417.x.

Pasmanik M., Callard G.V. 1988. A high abundance androgen receptor in goldfish brain: Characteristics and seasonal changes. Endocrinology 123 (2): 1162-1171. DOI: 10.1210/endo-123-2-1162.

Riley L.G., Hirano T., Grau E.G. 2002. Disparate effects of gonadal steroid hormones on plasma and liver mRNA levels of insulin-link growth factor-I and vitellogenin in the tilapia, Oreochromis mossambicus. Fish Physiology and Biochemistry 26 (3): 223-230. DOI: 10.1023/A:1026209502696.

Sabo-Attwood T., Kroll K.J., Denslow N.D. 2004. Differential expression of largemouth bass (Micropterus salmoides) estrogen receptor isotypes alpha, beta, and gamma by estradiol. Molecular and Cellular Endocrinology 218 (1-2): 107-118. DOI: 10.1016/j.mce.2003.12.007.

Scholz S., Kordes C., Hamann J., Gutzeit H.O. 2004. Induction of vitellogenin in vivo and in vitro in the model teleost medaka (Oryzias latipes): comparison of gene expression and protein levels. Marine Environmental Research 57 (3): 235-244. DOI: 10.1016/S0141-1136(03)00082-5.

Schreck C.B., Hopwood M.L. 1974. Seasonal androgen and estrogen patterns in the goldfish, Carassius auratus. Transactions of the American Fisheries Society 103 (2): 375-378. DOI: $10.1577 / 1548-8659(1974) 103<375$ :SAAEPI $>2.0 . C O ; 2$.
Shima A., Mitani H., 2004. Medaka as a research organism: past, present and future. Mechanisms of Development 121 (7-8): 599-604. DOI: 10.1016/j.mod.2004.03.011.

Socorro S., Power D.M., Olsson P.E., Canario A.M. 2000. Two estrogen receptors expressed in the teleost fish, Sparus aurata: cDNA cloning, characterization and tissue distribution. Journal of Endocrinology 166 (2): 293-306. DOI: 10.1677/joe.0.1660293.

Trudeau V.L., Turque N., Le Mével S., Alliot C., Gallant N., Coen L., Pakdel F., Demeneix B. 2005. Assessment of estrogenic endrocrine-disrupting chemical actions in the brain using in vivo somatic gene transfer. Environmental Health Perspective 113: 329-334. DOI: 10.1289/ehp.7418.

Zhang Z.B., Hu J.Y., Sai S.X., Zhao Y.B., Huang C., Tian X.J. 2008. [Gene cloning, sequence analysis and tissue expression of estrogen-related receptor alpha (Erralpha) in Japanese medaka and its transcriptional responses after differential EDCs exposure.] Huan Jing Ke Xue 29 (19): 3153-3158. [In Chinese.]

Weltzien F.-A., Andersson E., Andersen Ø., ShalchianTabrizi K., Norberg B. 2004. The brain-pituitary-gonad axis in male teleosts, with special emphasis on flatfish (Pleuronectiformes). Comparative Biochemistry and Physiology A 137 (3): 447-477. DOI: 10.1016/j.cbpb.2003.11.007.

Received: 11 March 2010

Accepted: 10 October 2010

Published electronically: 25 March 2011 